\title{
Galanin Causes Presynaptic Inhibition of Cholinergic Transmission in Rabbit Parasympathetic Ganglia
}

\author{
TOSHIHIKO NISHIMURA AND TAKASHI AKASU \\ Department of Physiology, Kurume University School of Medicine, \\ Kurume, 830 Japan
}

Received for publication November 25, 1994

\begin{abstract}
Key words: cholinergic neuron - acetylcholine - neuropeptide - urinary bladder - presynaptic inhibition
\end{abstract}

Galanin, a peptide with 29 amino acid residues, has been considered to be a neuropeptide, since its actions and immunoreactivity are reported to occur in both the central and peripheral nervous systems (Bauer et al. 1986; Crawley, 1990; Bartfai et al. 1992). In the autonomic nervous system, galanin induces a depression of cholinergic transmission (Tamura et al. 1987), a membrane hyperpolarization due to the activation of potassium channels (Tamura et al. 1988; Konopka et al. 1989) and a membrane depolarization (Konopka and Parsons, 1989). Galanin inhibits neuromuscular transmission in the human sacral parasympathetic pathway to the urinary bladder (Maggi et al. 1987). Galanin-like immunoreactivity is distributed in nerve fibers of the rat and human urinary bladder (Bauer et al. 1986). However an action of galanin in pelvic parasympathetic ganglia innervating the urinary bladder has not been reported. The aim of this study is to elucidate the effects of galanin on cholinergic transmission in rabbit vesical parasympathetic ganglia.
Male white rabbits were anesthetized with sodium pentobarbital $(40-50 \mathrm{mg} / \mathrm{kg}$, iv). The isolation of the vesical parasympathetic ganglia (VPG) on the surface of the urinary bladder has been described previously (Nishimura et al. 1988). Connective tissue surrounding the ganglia was removed as much as possible by a pin and surgical scissors. The ganglia with the pelvic nerve were then pinned onto a Sylgard block in a recording chamber $(0.5 \mathrm{ml}$ in volume) and continuously superfused with a Krebs solution ( $1 \mathrm{ml} / \mathrm{min})$ having the following composition (in $\mathrm{mM}$ ): $\mathrm{NaCl}, 117 ; \mathrm{KCl}$, 4.7; $\mathrm{CaCl}_{2}, 2.5 ; \mathrm{MgCl}_{2}, 1.2 ; \mathrm{NaH}_{2} \mathrm{PO}_{4}, 1.2$; $\mathrm{NaHCO}_{3}, 25$; and glucose 11. The solutions were aerated with $95 \% \mathrm{O}_{2}, 5 \% \mathrm{CO}_{2}$ and preheated to $35-37{ }^{\circ} \mathrm{C}$ at the recording site. The membrane potential was recorded by conventional intracellular recording techniques. Glass microelectrodes were filled with $3 \mathrm{M} \mathrm{KCl}$ and the tip resistances ranged from 30 to $50 \mathrm{M} \Omega$. An active bridge circuit was used for current injection into neurons through the recording microelectrode. Fast exci-

Reprint requests to: Dr. T. Nishimura, Department of Physiology, Kurume University School of Medicine, 67 Asahi-machi, Kurume, 830 Japan. 
tatory postsynaptic potentials (EPSPs) were evoked by electrical stimulation (5$30 \mathrm{~V}$ for $0.01-0.3 \mathrm{~ms}$ ) of the pelvic nerve at intervals of $5-30 \mathrm{~s}$, utilizing a suction electrode (Nishimura and Akasu, 1989). Signals from the microelectrode were continuously monitored with a penwriting chart recorder. The individual fast EPSPs were displayed on an oscilloscope with digitized memory and recorded on a pen-writing chart recorder.
Drugs were dissolved in Krebs solution and applied by changing the bath solutions with a three-way stopcock. Alternatively, acetylcholine (ACh) was applied by pressure ejection (20 psi for 10-300 ms) from a glass pipette containing $300-600 \mu \mathrm{M}$ ACh. All drugs were purchased from Sigma. Data are expressed as mean \pm SEM.

Bath application of porcine galanin ( $1 \mu \mathrm{M}$ for $5 \mathrm{~min}$ ) depressed the ampli-

A

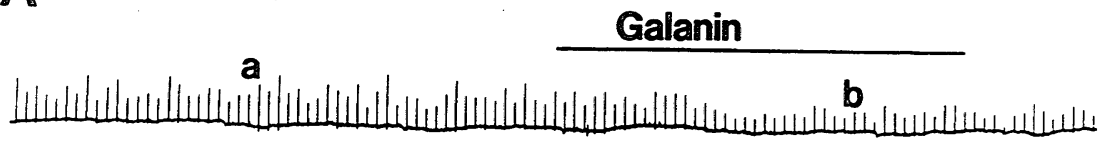

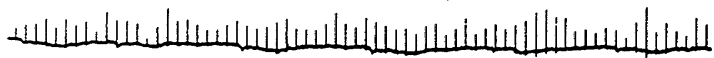

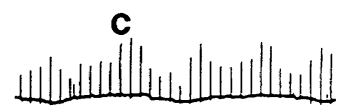

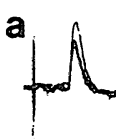<smiles>CCCCC(C)C</smiles><smiles>CCCC(C)C</smiles>

$10 \mathrm{mV}$

$10 \mathrm{mV}$

$30 \mathrm{msec}$

$60 \mathrm{sec}$

B

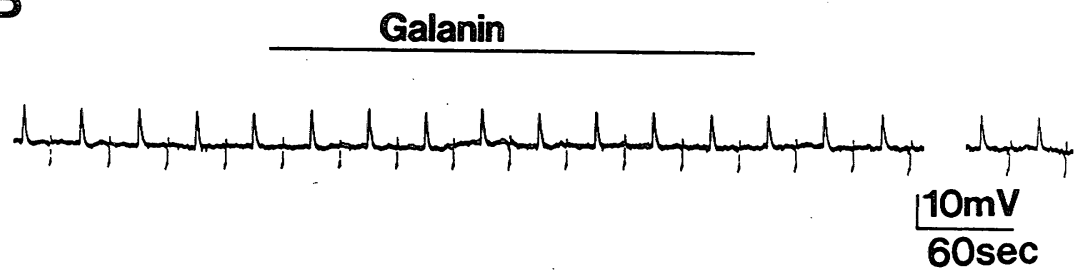

Fig. 1. A: effects of galanin on fast EPSPs. The upward deflections indicate the fast EPSPs. The horizontal bar indicates the time period for the application of galanin $(1 \mu \mathrm{M})$. The lower traces are expanded records of fast EPSPs at the times indicated by the respective letters in the upper trace. Three consecutive fast EPSPs are superimposed. The recovery record was obtained $15 \mathrm{~min}$ after washing out the peptide. $\mathrm{B}$ : effects of galanin on the ACh potentials in the presence of atropine (1 $\mu \mathrm{M})$. The downward deflections are electrotonic potentials evoked by anodal current injections $(0.2 \mathrm{nA}$ for $500 \mathrm{~ms})$. The right trace was recorded $10 \mathrm{~min}$ after washing out the peptide. 
tude of the fast EPSPs (Fig. 1A). In this neuron the mean amplitudes of the fast EPSPs were $11.5 \pm 0.4 \mathrm{mV}(\mathrm{n}=30)$ and $5.5 \pm 0.2 \mathrm{mV}(\mathrm{n}=30)$ in the absence and presence of galanin, respectively. The depression of the fast EPSP was reversed within 15 min after washing out the peptide. The fast EPSP was reversibly abolished by the application of $10 \mu \mathrm{M}$ (+)-tubocurarine or $100-200 \mu \mathrm{M}$ hexamethonium in all neurons $(n=10)$. The inhibitory effect of galanin was concentration-dependent. At concentrations of $100 \mathrm{nM}, \quad 300 \mathrm{nM}$ and $1 \mu \mathrm{M}, \quad$ galanin depressed the amplitude of the fast EPSPs by $17 \pm 5 \%(n=3), 39 \pm 8 \% \quad(n=3)$ and $65 \pm 7 \%(n=3)$, respectively. The galanin-induced inhibition of the fast EPSP did not display tachyphylaxis during prolonged application of the peptide (up to $10 \mathrm{~min}$; not shown). Galanin did not affect the resting potential or the input membrane resistance (Fig. 1A, B).

To determine the site of action for the galanin-induced inhibition of the fast EPSP, we next examined the effects of the peptide on nicotinic ACh potentials evoked by pressure application of ACh in the presence of atropine $(1 \mu \mathrm{M})$. Bath application of galanin $(1 \mu \mathrm{M}, 3 \mathrm{~min})$ did not affect the amplitude or time course of the ACh potential (Fig. 1B). The ACh potential was reversibly abolished by 10 $\mu \mathrm{M}$ (+)-tubocurarine or $100 \mu \mathrm{M}$ hexamethonium (not shown). These data indicate that galanin did not alter the sensitivity of the nicotinic receptors in the postganglionic neurons.

The present study demonstrates that galanin is a potent inhibitor of nicotinic transmission in rabbit vesical parasympathetic ganglia. The galanin receptors that suppress the fast EPSP must be located at the presynaptic nerve terminals, since the postsynaptic sensitivity to nicotinic agonists was not altered by galanin. This means that the activation of presynaptic galanin receptors depresses the amount of ACh liberated by action potentials in the preganglionic nerve terminals. Although the mechanism for the presynaptic effect of galanin is not known, galanin may reduce the calcium influx through voltage-gated calcium channels that are activated during the action potential (Tamura et al. 1988; Bartfai et al. 1992). Similar presynaptic inhibitory actions of galanin on cholinergic transmission have been reported in the guinea-pig myenteric plexus (Tamura et al. 1987) and hippocampus (see Bartfai et al. 1992). Also galanin modulates the resting potential in guineapig myenteric neurons (Tamura et al. 1988) and mudpuppy cardiac neurons (Konopka and Parsons, 1989; Konopka et al. 1989). However galanin did not affect the resting potential of neurons in the rabbit VPG. There may be a different expression of these receptors between species and/or ganglia. The physiological role of the presynaptic galanin receptors remains to be clarified. The galanininduced depression of cholinergic transmission may contribute to the neural inhibition of the sacral parasympathetic pathway to the urinary bladder, thereby inhibiting the micturition reflex and causing a retention of urine.

Acknowledgments: The authors express their thanks to Ms. Yoshitake and Miss Mikashima for their secretarial assistance. This work was supported in part by a Grant- 
in-Aid for Scientific Research from the Ministry of Education, Science and Culture of Japan and The Ishibashi Research Fund.

\section{References}

Bartfal, T., Fisone, G. and Langel, U. (1992). Galanin and galanin antagonists: molecular and biochemical perspectives. Trends Pharmacol. Sci. 13, 312-317.

Bauer, F.E., Christofides, N.D., Hacker, G.W., Blank, M.A., Polak, J.M. et al. (1986). Distribution of galanin immunoreactivity in the genitourinary tract of man and rat. Peptides 7, 5-10.

CRawley, J.N. (1990). Coexistence of neuropeptides and "classical" neurotransmitters. Functional interactions between galanin and acetylcholine. Ann. N. Y. Acad. Sci. 579, 233245.

Konopka, L.M., McKeon, T.W. and Parsons, R.L. (1989). Galanin-induced hyperpolarization and decreased membrane excitability of neurones in mudpuppy cardiac ganglia. J. Physiol. 410, 107-122.

KonopKa, L.M. and Parsons, R.L. (1989).
Characteristics of the galanin-induced depolarization of mudpuppy parasympathetic postganglionic neurons. Neurosci. Lett. 99, 142-146.

Maggi, C.A., Santicioli, P., Patacchini, R., Turini, D., Barbanti, G. et al. (1987). Galanin: a potent modulator of excitatory neurotransmission in the human urinary bladder. Eur. J. Pharmacol. 143, 135-137.

Nishimura, T. and Akasu, T. (1989). 5-Hydroxytryptamine produces presynaptic facilitation of cholinergic transmission in rabbit parasympathetic ganglia. J. Auton. Nerv. Syst. 26, 251-260.

Nishimura, T., Toktmasa, T. and Akasu, T. (1988). Calcium-dependent potassium conductance in neurons of rabbit vesical pelvic ganglia. J. Auton. Nerv. Syst. 24, 133-145.

Tamura, K., Palmer, J.M., Winkelmann, C.K. and WooD, J.D. (1988). Mechanism of action of galanin on myenteric neurons. J. Neurophysiol. 60, 966-979.

TAmura, K., Palmer, J.M. and Wood, J.D. (1987). Galanin suppresses nicotinic synaptic transmission in the myenteric plexus of guinea-pig small intestine. Eur. J. Pharmacol. 136, 445446. 